\title{
Małgorzata Stojek*
}

\section{The concentration of molybdenum and copper in rocks, soils and plants in the area of Jabłonki (Eastern Beskids Mts.)}

\section{Zawartość molibdenu i miedzi w skałach, glebach i roślinach w okolicy Jabłonek (Beskidy Wschodnie)}

\footnotetext{
${ }^{*}$ Mgr Małgorzata Stojek, Polish Geological Institute, National Research Institute, Rakowiecka 4 St, 00-975 Warsaw, Poland;

e-mail: malgorzata.mrowiec@pgi.gov.pl
}

Keywords: menilite shales, sandstones, molybdenum, copper, bioaccumulation, Eastern Beskids

Słowa kluczowe: łupki menilitowe, piaskowce, molibden, miedź, bioakumulacja, Beskidy Wschodnie

\begin{abstract}
Molybdenum is one of the major trace elements for plants, but its excess and the deficiency of copper in soils can lead to the production of feed that may be toxic to animals and cause molybdenosis Menilite shales that occur in the Eastern Beskids Mts. are characterised by an elevated content of this element. The concentration of molybdenum and copper has been determined in samples of bedrock, soils and plants (Trifolium hybridum L. and Plantago major L. plants), taken in the area of occurrence of menilite shales and the Otryt Sandstones. The molybdenum concentration in rocks varies from 0.80 to $40 \mathrm{mg} / \mathrm{kg}$, in soils - from 1.97 to $19.58 \mathrm{mg} / \mathrm{kg}$, and in plant material - from 0.54 to $11.76 \mathrm{mg} / \mathrm{kg}$. The copper concentration in rocks ranges from 11 to $111 \mathrm{mg} / \mathrm{kg}$, in soils - from 23 to $76 \mathrm{mg} / \mathrm{kg}$, and in plants - up to $20 \mathrm{mg} / \mathrm{kg}$. The average Mo concentration in all kinds of plants is significantly higher in the area of occurrence of menilite shales than in the area where the Otryt Sandstones are dominant. The higher content of Mo in the samples collected from clover was accompanied by the lower $\mathrm{Cu} / \mathrm{Mo}$ ratio, which may cause a molybdenosis disease in animals in the study area.
\end{abstract}

(c) IOŚ-PIB

\section{INTRODUCTION}

Molybdenum is the 54th most common element in the Earth's crust $(1.2 \mathrm{mg} / \mathrm{kg})$. This is a strongly chalcophile element forming several minerals, of which the most important are molybdenite $\left(\mathrm{MoS}_{2}\right)$, wulfenite $\left(\mathrm{PbMoO}_{4}\right)$ and powellite $\left(\mathrm{CaMoO}_{4}\right)$. In igneous and metamorphic rocks, Mo is most common in feldspars and biotite. In sedimentary rocks, it is strongly complexed by organic matter and absorbed by iron compounds [de Vos et al. 2006]. In the hypergenic zone, molybdenum mobilised due to weathering processes is readily bound by organic matter, clay minerals and Al-Fe-Mn hydroxides [Kabata-Pendias 1996]. Its average contents in igneous rocks, depending on the rock type, are in the range of $0.2-2 \mathrm{mg} / \mathrm{kg}$, in clayey rocks $-2-2.5 \mathrm{mg} / \mathrm{kg}$, in carbonates $-0.2-0.4 \mathrm{mg} / \mathrm{kg}$ and in sandstones - 0.2-0.8 mg/kg [KabataPendias, Mukherjee 2007]. Higher molybdenum concentrations are found in copper-bearing and bituminous shales, ranging up to $200 \mathrm{mg} / \mathrm{kg}$, and in caustobioliths - up to $2 \%$ [Pasieczna 2012] The average molybdenum concentration in soils of the world has been determined at $1.8 \mathrm{mg} / \mathrm{kg}$, although, depending on its concentration in the parent rocks, it ranges from 1.3 in sandy soils to $2.8 \mathrm{mg} / \mathrm{kg}$ in calcareous soils [Kabata-Pendias, Mukherjee 2007] In Europe, the subsoil layer contains from $<0.1$ to $17.2 \mathrm{mg} / \mathrm{kg}$ of molybdenum [de Vos et al. 2006]. In the territory of Poland, the value of molybdenum geochemical background is variable. The

\section{Streszczenie}

Molibden jest jednym z podstawowych mikroelementów dla roślin, ale jego nadmiar w glebach przy niedoborze miedzi może prowadzić do produkcji pasz, które moga być toksyczne dla zwierząt i powodować molibdenozę. Łupki menilitowe występujące na obszarze Beskidów Wschodnich charakteryzuja się podwyższona zawartością tego pierwiastka. W próbkach skał podłoża, gleb oraz roślin (rośliny Trifolium hybridum L. i Plantago major L.) pobranych na terenie występowania łupków menilitowych oraz piaskowców z Otrytu oznaczono zawartości molibdenu i miedzi. Zawartość molibdenu w skałach wynosi od $0,80 \mathrm{mg} / \mathrm{kg}$ do $40 \mathrm{mg} / \mathrm{kg}$, w glebach jest w zakresie 1,97-19,58 mg/kg, a w materiale roślinnym jest w przedziale od 0,54 do $11,76 \mathrm{mg} / \mathrm{kg}$. Zawartość miedzi zmieniała się w skałach od $11 \mathrm{mg} / \mathrm{kg}$ do $111 \mathrm{mg} / \mathrm{kg}$, w glebach od 23 do $76 \mathrm{mg} / \mathrm{kg}$ i badanych roślinach do $20 \mathrm{mg} / \mathrm{kg}$. Średnia zawartość Mo we wszystkich rodzajach roślin jest zdecydowanie wyższa na terenie występowania łupków menilitowych niż na obszarze gdzie dominują piaskowce z Otrytu. Z wyższą zawartością Mo w próbkach koniczyny wiąże się niższa wartość stosunku Cu/Mo, co może skutkować występowaniem molibdenozy u zwierzat w badanym rejonie.

topsoil layer in most areas of the country contains $<0.45 \mathrm{mg} / \mathrm{kg}$ of molybdenum [Pasieczna 2012]. In the Carpathians, the molybdenum concentration is much higher and can attain $144 \mathrm{mg} / \mathrm{kg}$, with an average of $35 \mathrm{mg} / \mathrm{kg}$. The most likely source of molybdenum is the silica-clay-marl menilite layers that have an elevated content of this element [Gucwa, Wieser 1980]. In soils, molybdenum is present predominantly in anionic forms. The $\mathrm{MoO}_{4}{ }^{2-}$ anion predominates in neutral and moderately alkaline soils, and is the most easily available form to plants. The $\mathrm{HMoO}_{4}{ }^{-}$ion is present in soils with lower pH values. These anions are easily co-precipitated by iron hydroxides and absorbed by organic matter. In the literature, it is most frequently reported that the molybdenum concentration in soil solutions is in the range of $0.8-8 \mathrm{mg} / \mathrm{l}$ and is higher in the cambic and accumulation horizons. In the case of $\mathrm{Cu}$, the most common values of its concentrations in the soils of Poland vary from 3 to $15 \mathrm{mg} / \mathrm{kg}$ [Kabata-Pendias, Pendias 1993]. Molybdenum is an essential element required for the normal development and growth of both plants and animals. Terrestrial plants collect metals mainly from the soil solution through the root system [Eapen, d 'Souza 2004]. The availability of Mo to plants is closely related to the $\mathrm{pH}$ value of the soil and to the amount of iron oxides and organic constituents. In acidic soils $(\mathrm{pH}<5.5)$ that contain much iron, the availability of Mo to plants is very low 
[Kabata-Pendias, Pendias 1993]. Some plants have a specific potential for the bioaccumulation of molybdenum above their physiological needs, e.g. legumes. They can accumulate up to about 350 ppm Mo without any signs of toxicity [Kabata-Pendias 2011]. The occurrence of Mo toxicity in plants is sparse; however, high molybdenum concentrations in animal feed may cause copper deficiency in ruminants and induce the so-called molybdenosis, especially in animals that graze in dry areas, where there are soils with high organic matter content [He et al. 2005]. Molybdenum may affect the availability of copper to animals only in the presence of sulphur due to the formation of an insoluble compound representing sulphosalts $-\mathrm{CuMoS}_{4}$ [Fisher George 2008]. Demand for Mo in ruminants varies between 0.1 and $3.5 \mathrm{mg} / \mathrm{kg}$; for $\mathrm{Cu}$ - between 5 and $25 \mathrm{mg} / \mathrm{kg}$ DM feed [Kubiński 1996]. Animal feed containing 10-20 ppm Mo can cause molybdenosis in ruminants. The greatest susceptibility to molybdenosis is observed in cattle, sheep, horses and pigs [Singh 2005]. Average molybdenum contents in plants, depending on their type, are in the range of $0.04 \mathrm{mg} / \mathrm{kg}$ (carrot root) to $1.0 \mathrm{mg} / \mathrm{kg}$ (wheat). In the grass of meadows, where cattle graze and no toxicity effects are observed in animals, the molybdenum content is below $1 \mathrm{mg} / \mathrm{kg}$. In the grass of grasslands, where negative impact on the health of grazing animals is observed, the content is higher and amounts to a few and locally even tens of $\mathrm{mg} / \mathrm{kg}$.

The aim of this study was to trace the migration of molybdenum from the bedrock through the soil to the plant. Previous geochemical studies on molybdenum content in the area of the Dukla Folds in the Bieszczady Mts. showed a relationship between the occurrence of areas with high molybdenum content in modern alluvial sediments and the occurrence of menilite beds. Increased contents were observed in sediments, e.g. in the river systems of Wetlinka, Dołżyczka, Solinka and Jabłonka. The highest molybdenum contents were found to the north of the village of Cisna $(10.6 \mathrm{mg} / \mathrm{kg})$ and to the west of the village of Przysłup $(10.8 \mathrm{mg} / \mathrm{kg})$ [Bojakowska, Borucki 1994].

\section{MATERIAL AND METHODS}

The working area is located south of Jabłonki in the district of Lesko, Poodkarpackie Voivodeship. Geochemical studies were carried out in the border zone with the northeastward located tectonic unit of the Bystre Slice (Fig. 1).

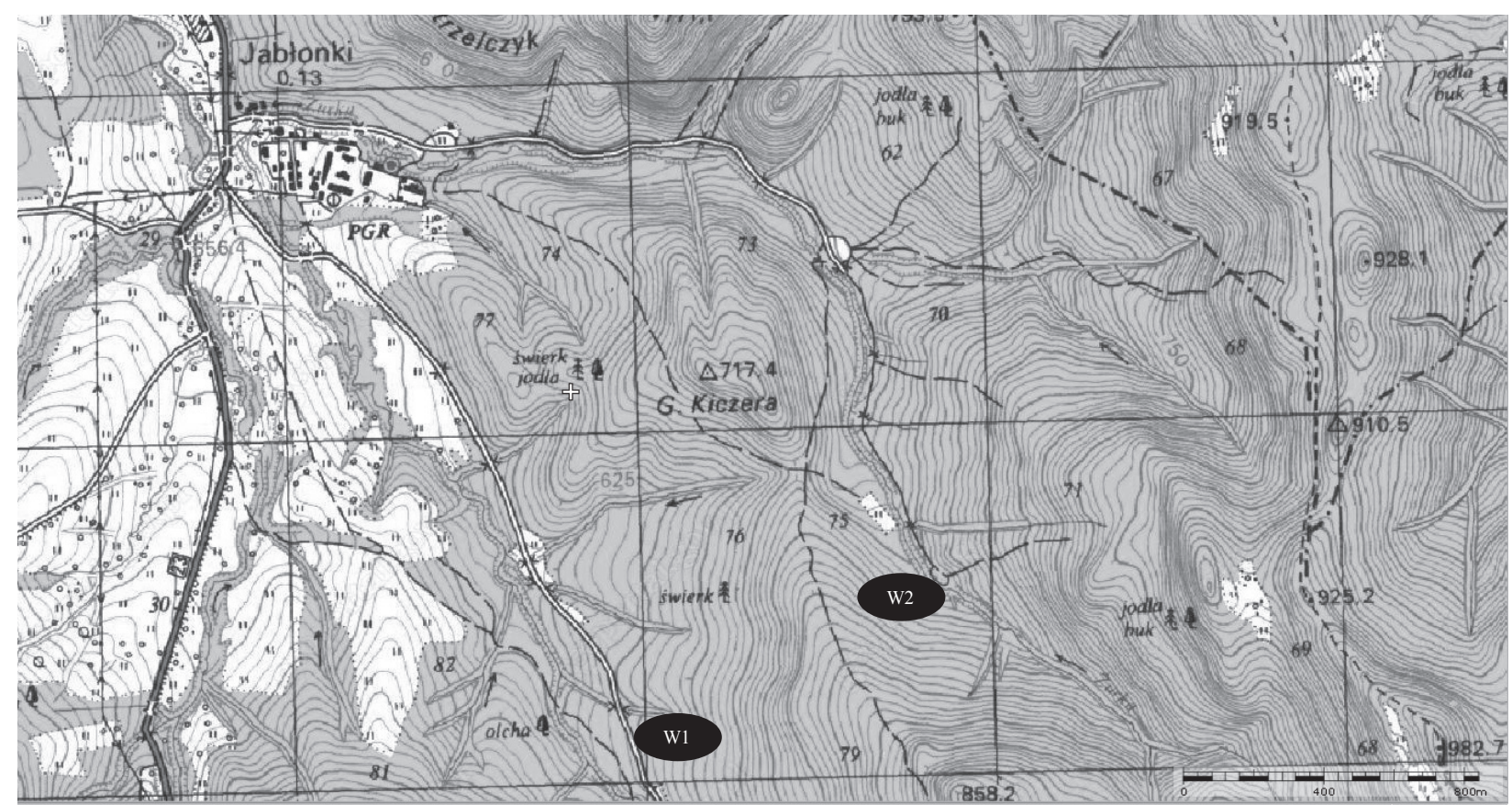

Fig. 1. Location of sampled sites.

The samples of rocks, soils and plants were collected at two locations: W1 - in the area of menilite shales and W2 - in the area of the Otryt Sandstones. A total of 80 samples of four plant species were taken at location W1: from alsike clover, red clover, greater plantain and ribwort plantain. Soil samples were collected from four holes spaced $0.5 \mathrm{~m}$, and then averaged (mixed). At location W1, soil samples were collected from two depth levels: from the interval down to $30 \mathrm{~cm}$ and from the $30 \mathrm{~cm}-1.0 \mathrm{~m}$ interval. At this site, five rock samples were also collected. A total of 40 samples of two different species of plants were collected at location W2: from alsike clover and greater plantain. Soil samples were taken from three holes spaced $0.5 \mathrm{~m}$, and then averaged (mixed). Due to the very shallow soil profile and the high proportion of rock fragments, the soil was taken from one level down to a depth of $30 \mathrm{~cm}$. At this site, two rock samples were also taken.

To properly prepare the samples for testing, plant samples were purified and then dried in dryers at a temperature not exceeding $38^{\circ} \mathrm{C}$. Dried material was ground and digested in a Multiwave 3000 microwave oven $\left(70-71 \% \mathrm{HNO}_{3}+30 \% \mathrm{H}_{2} \mathrm{O}_{2}\right)$. Soil and rock samples were air-dried at room temperature. Thereafter, soil samples were digested in aqua regia $\left(65 \% \mathrm{HNO}_{3}+37-38 \% \mathrm{HCl}\right)$ and the rocks were subjected to complete acid degradation $(65 \% \mathrm{HNO} 3+$ $\left.37-38 \% \mathrm{HCl}+70 \% \mathrm{HClO}_{4}+38 \% \mathrm{HF}\right)$. After digestion, the contents of molybdenum and copper were determined in all samples using the ICP-MS method and a Perkin Elmer Elan DRC II mass spectrometer with inductively coupled plasma. The determination limit for $\mathrm{Mo}$ and $\mathrm{Cu}$ is $0.05 \mathrm{mg} / \mathrm{kg}$. In addition, the soil samples were analysed for $\mathrm{pH}$ in the aqueous extract using the potentiometry method. All tests were performed at the Central Chemical Laboratory of the PGI in Warsaw, accredited for the analyses. As the reference materials, RGM-1 - rhyolite and TB - clay shale were used for the study. Reference materials, used for interlaboratory comparisons (921 Riverclay from ISE comparison; grass from IPE comparison) and organised by the University of Wageningen, were also employed. 


\section{RESULTS AND DISCUSSION}

3.1 Plants

The average molybdenum concentration in plants of four species from location W1: alsike clover, red clover, greater plantain and ribwort plantain, range from 1.3 to $12 \mathrm{mg} / \mathrm{kg}$ (Table 1). The maximum concentration of $12 \mathrm{mg} / \mathrm{kg}$ was found in Trifolium hybridum $\mathrm{L}$. The copper content of the above-mentioned plant species varies from 12 to $20 \mathrm{mg} / \mathrm{kg}$, the highest $\mathrm{Cu}$ concentration was measured in Trifolium pratense $\mathrm{L}$. In the case of plants taken from location W2, the average Mo concentrations are $0.80 \mathrm{mg} / \mathrm{kg}$ in Trifolium hybridum L. and $0.54 \mathrm{mg} / \mathrm{kg}$ in Plantago major L., and the Cu concentrations are 11 and $16 \mathrm{mg} / \mathrm{kg}$, respectively. A comparison of the average Mo concentrations in plants growing on various substrates is presented in Fig. 2 .

Tested plants are characterised by Mo contents significantly higher than the average. Molybdenum concentrations in plants are usually $0.2-2.0 \mathrm{mg} / \mathrm{kg}$ DM [Ruszkowska, Wojcieska-Wykupajtys 1996]. The most common Mo content in red clover is $0.50 \mathrm{mg} / \mathrm{kg}$, and in grass (orchard grass) $-0.33 \mathrm{mg} / \mathrm{kg}$. In areas with molybdenum toxicity in cattle, grass species contained an average of about $3 \mathrm{mg} / \mathrm{kg}$, and clover specimens about $25 \mathrm{mg} / \mathrm{kg}$ DM of this metal [Kabata-Pendias, Pendias 1993; Kabata-Pendias 1996]. Tested plants are characterised by copper contents similar to the average values. The copper concentration in red clover commonly varies from 4 to $21 \mathrm{mg} / \mathrm{kg}$, and in grasses (orchard grass) - from 2 to $20 \mathrm{mg} / \mathrm{kg}$ [Kabata-Pendias 1996].

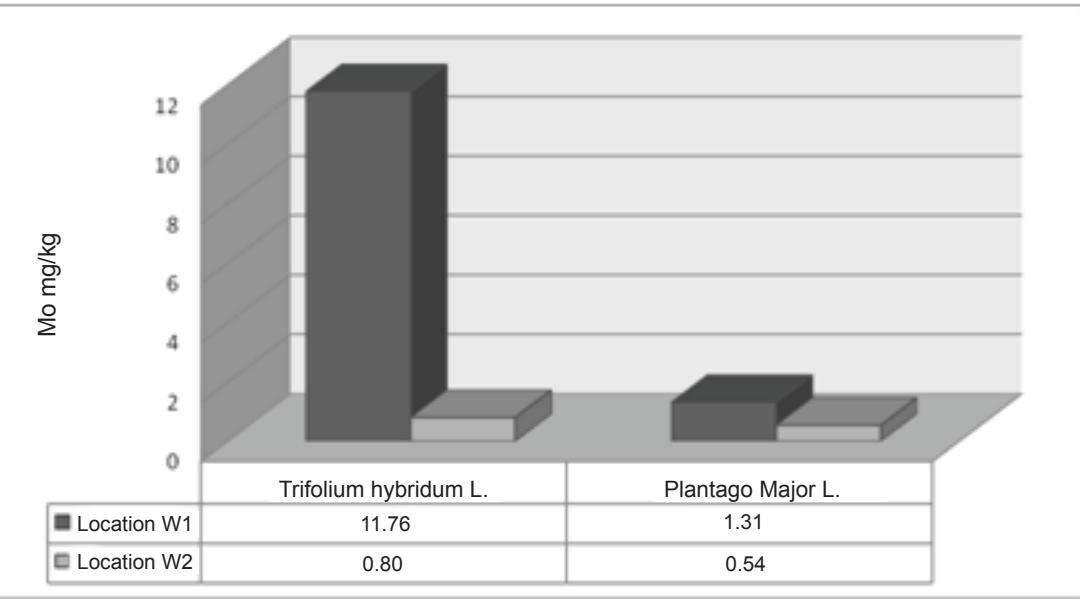

Fig. 2. The average molybdenum concentrations in plants growing on the substrate composed of menilite shales and sandstones.

Table 1. Average concentrations of molybdenum and copper in plants growing in areas composed of menilite shales and sandstones

\begin{tabular}{|l|c|c|c|}
\hline Species & Cu mg/kg & Mo $\mathrm{mg} / \mathrm{kg}$ & Cu/Mo ratio \\
\hline Location W1 & & & 11.1 \\
\hline Trifolium hybridum $L$. & 11.76 & 9.76 & $2: 1$ \\
\hline Trifolium pratense $L$. & 19.19 & 1.31 & $15: 1$ \\
\hline Plantago major $L$. & 19.09 & 1.58 & $11: 1$ \\
\hline Plantago lanceolata $L$. & 17.88 & & $14: 1$ \\
\hline Location W2 & & 0.80 & $29: 1$ \\
\hline Trifolium hybridum $L$. & 11.04 & 0.54 & \\
\hline Plantago major $L$. & 15.55 & & \\
\hline
\end{tabular}

Explanation: W1, menilite shales area; W2, Otryt Sandstones area

\subsection{Soils}

The average Mo content in soil at location W1 from a depth down to $30 \mathrm{~cm}$ is $10 \mathrm{mg} / \mathrm{kg}$, and in soil from a depth $>30 \mathrm{~cm}$ to $20 \mathrm{mg} / \mathrm{kg}$. The Cu contents are 42 and $76 \mathrm{mg} / \mathrm{kg}$, respectively. The soil $\mathrm{pH}$ is acidic and the $\mathrm{pH}$ value is 5.46 in the topsoil layer and 6.14 in the subsoil layer $(>30 \mathrm{~cm})$. The average Mo content in soil from location W2 is $1.97 \mathrm{mg} / \mathrm{kg}$, and the Cu content is $23 \mathrm{mg} / \mathrm{kg}$. The soil $\mathrm{pH}$ is basic -7.45 . Soils from location $\mathrm{W} 1$ are characterised by a significantly higher $\mathrm{Cu}$ content when compared with the average copper content in soils of the Polish Lowlands (the average content in sandy podsol is $6 \mathrm{mg} / \mathrm{kg}$, in alluvial soil $-24 \mathrm{mg} / \mathrm{kg}$ ). The $\mathrm{Cu}$ concentration in soils from location W2 is comparable with the most commonly observed Cu contents [Kabata-Pendias, Pendias 1993].

\subsection{Rocks}

The investigations have revealed that the molybdenum concentration in rocks at location W1 ranges from 2.58 to $40 \mathrm{mg} / \mathrm{kg}$, and the average content is $17.91 \mathrm{mg} / \mathrm{kg}$. This is due to the presence of brown shales (characteristic of the menilite bed) as well as grey calcareous shales and thin- to medium-bedded sandstones. The $\mathrm{Cu}$ concentration varies from 31 to $111 \mathrm{mg} / \mathrm{kg}$. The average Mo content at location W2 is $0.80 \mathrm{mg} / \mathrm{kg}$, and the average Cu content $-11 \mathrm{mg} / \mathrm{kg}$. Compared with the commonly found average molybdenum contents in clay deposits $(2-2.5 \mathrm{mg} / \mathrm{kg}$ ) [Kabata-Pendias 2011], the examined rocks are characterised by much higher Mo contents. Sandstones that occur in this area are also characterised by higher molybdenum content when compared with limestones $(0.4 \mathrm{mg} / \mathrm{kg})$ and sandstones $(0.2 \mathrm{mg} / \mathrm{kg})$ [He et al. 2005]. The average copper concentration in rocks from location $\mathrm{W} 1$ is $74 \mathrm{mg} / \mathrm{kg}$. It is greater than the $\mathrm{Cu}$ content in clay rocks, ranging between 40 and $60 \mathrm{mg} / \mathrm{kg}$. At location W2, the Cu concentration is $11 \mathrm{mg} / \mathrm{kg}$, and the figure is similar to the most commonly encountered $\mathrm{Cu}$ contents in sandstones -5 to $30 \mathrm{mg} / \mathrm{kg}$ [Kabata-Pendias 1996]. The results of the work indicate that there is a correlation between the molybdenum concentration in the substrate and the concentration of this element in clover. The increased Mo contents and thus 
the demand of legumes are due to participation of this metal in the processes of assimilation of atmospheric nitrogen and protein metabolism [Kabata-Pendias, Pendias 1996]. In the area of occurrence of menilite shales, the average Mo content is elevated in rocks (18 mg/kg), soil <30 cm (10 mg/kg), soil $>30 \mathrm{~cm} \mathrm{(20} \mathrm{mg/kg)}$ and leguminous plants (12 mg/kg; Fig. 3 ), in contrast to the samples taken from the Otryt Sandstone layer where the Mo contents are $0.80 \mathrm{mg} / \mathrm{kg}$ in rocks, $2 \mathrm{mg} / \mathrm{kg}$ in soils and $0.80 \mathrm{mg} / \mathrm{kg}$ in clover
(Fig. 4). The concentration of molybdenum in soils generally reflects its occurrence in parent rocks [Kabata-Pendias 1996]. In Poland, there are two clearly marked geochemical provinces: northern and southern, related to the geological structure of the country. Soils of the Northern Province, which developed on Quaternary sandy glaciofluvial and fluvial deposits, contain small amounts of Mo, whereas the Carpathian soils are characterised by enrichment in this element [Pasieczna 2012].

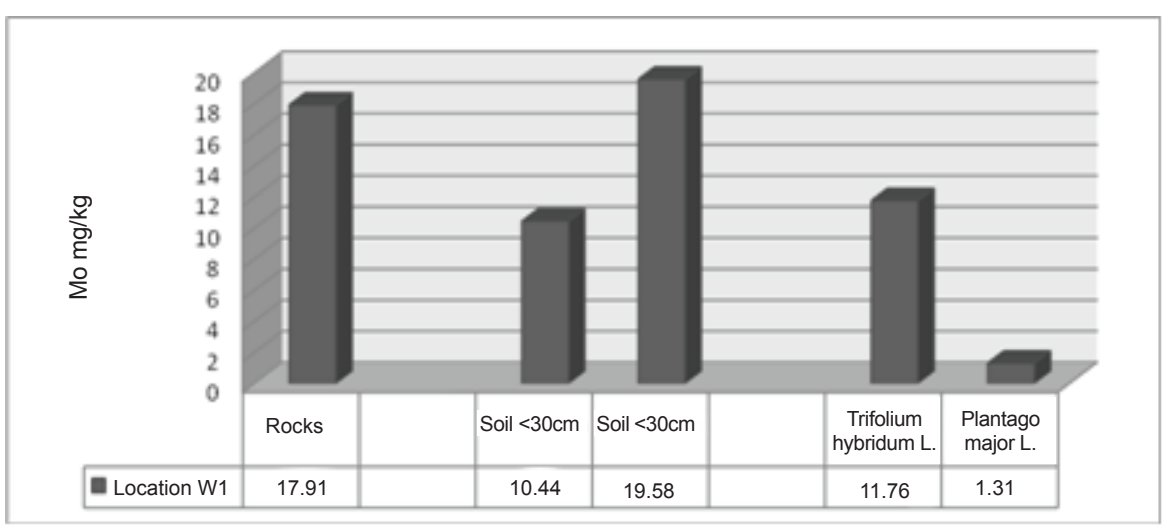

Fig. 3. Average molybdenum concentration in rocks, soil and plants in the area of menilite shales.

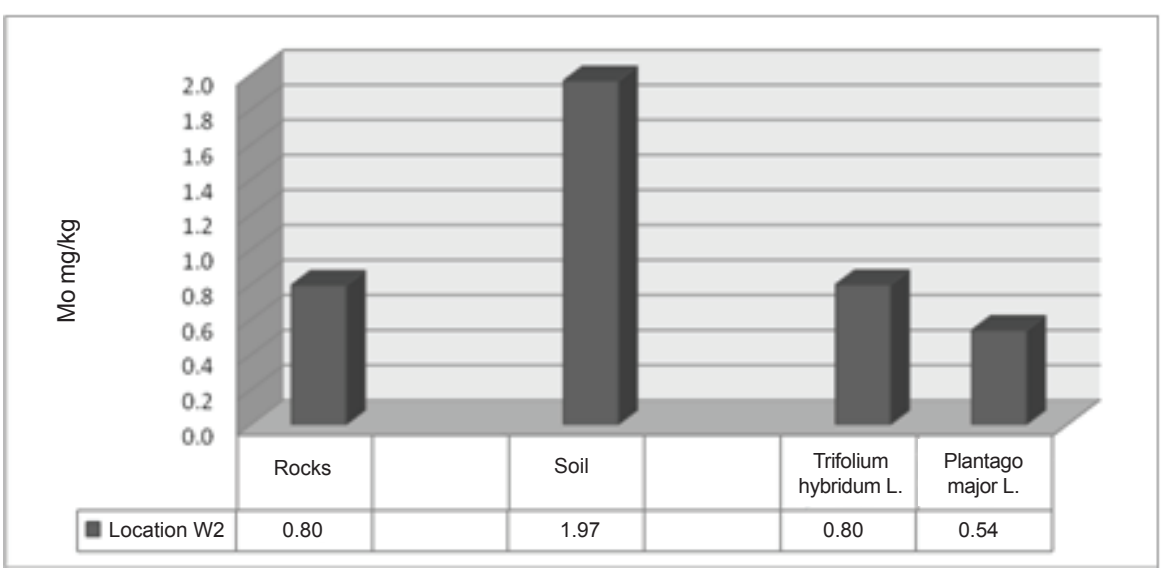

Fig. 4. Average molybdenum concentration in rocks, soil and plants in the area of the Otryt Sandstone.

The elevated molybdenum concentrations in clover correlate with the lower ratio of Cu/Mo (Table 1). In the case of both Trifolium hybridum L. and Trifolium pratense L., the Cu/Mo ratio is below 4-5, which may indicate the potential for the occurrence of Mo toxicity in those areas. In plants that do not exhibit excessive accumulation of Mo, the Cu/Mo ratio is 15:1 for Plantago major L. and 11:1 for Plantago lanceolata L. In the case of plants collected from location W2, the Cu/Mo ratio is 14:1 for Trifolium hybridum L. and 29:1 for Plantago major $\mathrm{L}$. The Cu:Mo ratio in the food ratio is a very important factor. The optimal ratio is $6: 1$, the limit ratio is $2-3: 1$ and the toxic ratio is lower than 2:1 [Kubiński 1996].

\section{CONCLUSIONS}

1. The Mo concentration determined in rocks, soils and plants is significantly higher in the area of occurrence of menilite shales than in the area where the dominant rock is the Otryt Sandstone.
2. Mo accumulation by plants of the Fabaceae family (alsike clover) is greater than by plants of the Plantaginaceae family (greater plantain).

3. In areas with naturally elevated Mo concentration in soils and rocks, forage crops, such as alsike clover, show high accumulation of this element (12 mg/kg). It can cause molybdenosis in both farmed and wild animals.

This paper has been prepared based on the results obtained during the implementation of the research project entitled "Bioaccumulation of molybdenum and other trace elements in plants in the area of occurrence of menilite shales", financed from the funds of the PGI-NRI for statutory activities.

\section{ACKNOWLEDGEMENTS}

The author thanks Prof. Dr Hab. Isabella Bojakowska for scientific assistance and valuable comments during preparation of the paper. 


\section{REFERENCES}

BOJAKOWSKA, I, BORUCKI, J 1994, 'Molybdenum in stream sediment on the area of occurrence of the Dukla Folds and their margin', Geol. Q., vol. 38, pp. 155-168.

DE VOS, W, TARVAINEN, T, (CHIEF-EDITORS), SALMINEM, R, REEDER, S, DE VIVO, B, DEMETRIADES, A, PIRC, S, BATISTA, M, MARSINA, K, OTTESEN, RT, O'CONOR, PJ, BIDOVEC, M, LIMA, A, SIEWERS, U, SMITH, B, TAYLOR, H, SHAW, R, SALPETEUR, I, GREGORAUSKIENE, V, HALAMIC, J, SLANINKA, I, LAX, K, GRAVESEN, P, BIRKE, M, BREWARD, N, ANDER, EL, JORDAN, G, DURIS, M, KLEIN, P, LOCUTURA, J, BEL-LAN, A, PASIECZNA, A, LIS, J, MAZREKU, A, GILUCIS, A, HEITZMANN, P, KLAVER, G, PETERSELL, V 2006, Geochemical Atlas of Europe. Part 2.-Geological Survey of Finland, Espoo.

EAPEN, S, D'SOUZA, SF 2004, 'Prospects of genetic engineering of plants for phytoremediation of toxic metals', Biotechnol. Adv., vol. 23, pp. 97-114.

FISHER GEORGE, EJ 2008, 'Micronutrients and animal nutrition and the link between the application of micronutrients to crops and animal health', Turk. J. Agric. For. 32, pp. 221-233.

GUCWA, I, WIESER, T 1980, 'Geochemia i mineralogia skał osadowych fliszu karpackiego zasobnych w materię organiczna', Pr. Miner., vol. 69, pp. 1-43.
HE ZHENLI, L, YANG XIAOE, E, STOFFELLA PETER, J 2005, 'Trace elements in agroecosystems and impacts on the environment', J. Trace Elem. Med. Bio., vol. 19, pp. 125-140.

KABATA-PENDIAS, A 1996, 'Biogeochemia miedzi i molibdenu', PAN, zeszyt 14: pp. 11-19, Warszawa.

KABATA-PENDIAS, A 2011, 'Trace elements in soils and plants', CRC Press: pp. 190-198, Boca Raton.

KABATA-PENDIAS, A, MUKHERJEE, AB 2007, 'Trace elements from soil to human', Springer-Verlag, Berlin.

KABATA-PENDIAS, A, PENDIAS, H 1993, 'Biogeochemia pierwiastków śladowych', PWN, Warszawa.

KABATA-PENDIAS, A 1996, 'Biogeochemia miedzi i molibdenu PAN, zeszyt 14: pp. 11-19, Warszawa.

KUBIŃSKI,T 1996, 'Rola miedzi i molibdenu w żywieniu zwierząt, PAN, zeszyt 14: pp. 210-215, Warszawa.

PASIECZNA, A 2012, 'Molibden i cyna w glebach Polski', Biuletyn Państwowego Instytutu Geologicznego, vol. 450, pp. 75-82.

RUSZKOWSKA, M, WOJCIESKA-WYKUPAJTYS, U 1996, 'Fizjologiczne i biochemiczne funkcje miedzi i molibdenu w roślinach' PAN, zeszyt 14: pp. 104-110, Warszawa.

SINGH, VP 2005, 'Metal toxicity and tolerance in plants and animals', Sarup \& Sons, New Delphi. 